\title{
Renoprotective effects of renin-angiotensin-aldosterone system blockers in type 2 diabetes: demystifying multiple treatment comparisons in a network meta-analysis. Reply to Catalá-López F [letter]
}

\author{
P. Vejakama • A. Thakkinstian • J. Attia
}

Received: 1 May 2012 / Accepted: 2 May 2012 / Published online: 30 June 2012

(C) Springer-Verlag 2012

Keywords Angiotensin-converting enzyme inhibitors . Angiotensin receptor blockers $\cdot$ Network meta-analysis $\cdot$ Systematic review $\cdot$ Type 2 diabetes

\section{Abbreviations \\ ACEI ACE inhibitor \\ ARB Angiotensin II receptor blocker}

To the Editor: We read with interest the letter from $\mathrm{Dr}$ Catalá-López [1] commenting on our paper [2]. We performed a network meta-analysis of the reno-protective effects of renin-angiotensin-aldosterone system blockers in type 2 diabetic patients [2]. We combined ACE inhibitors (ACEIs) and angiotensin II receptor blockers (ARBs), similar to the previous meta-analysis that compared the combined effects only to placebo [3]. Most importantly,

P. Vejakama $\cdot$ A. Thakkinstian $(\bowtie)$

Section for Clinical Epidemiology and Biostatistics,

Faculty of Medicine, Faculty of Medicine, Ramathibodi Hospital,

Mahidol University,

Rama 6 Road, Rachatevi,

Bangkok 10400, Thailand

e-mail: raatk@mahidol.ac.th

P. Vejakama

Bundarik Hospital,

Ubon Ratchathani Province, Thailand

\section{J. Attia}

Centre for Clinical Epidemiology and Biostatistics,

School of Medicine and Public Health, University of Newcastle, and Hunter Medical Research Institute,

Newcastle, NSW, Australia there was very little evidence of any heterogeneity to suggest that ACEIs and ARBs are substantially different. Furthermore, current guidelines for kidney protection in diabetic patients [4] recommend the prescription of either ACEIs or ARBs.

We acknowledge that, because of its sample size, the study by Lewis et al [5] was the greatest contributor to the pooled RR for end-stage renal disease in direct metaanalysis $(89.7 \%)$. We also acknowledge differences in the design of trials included in the analysis; however, this is quite common when performing a meta-analysis. We did not include the olmesartan trial [6], because this was published after the end of our search (July 2011).

Duality of interest The authors declare that there is no duality of interest associated with this manuscript.

Contribution statement All three authors were responsible for the conception and design of the manuscript, drafting the article and revising it critically for important intellectual content. All authors approved the version to be published.

\section{References}

1. Catalá-López F (2012) Renoprotective effects of renin-angiotensin-aldosterone system blockers in type 2 diabetes: demystifying multiple treatment comparisons in a network meta-analysis. Diabetologia. doi:10.1007/s00125-012-2619-9

2. Vejakama P, Thakkinstian A, Lertrattananon D, Ingsathit A, Ngarmukos C, Attia J (2012) Reno-protective effects of renin-angiotensin system blockade in type 2 diabetic patients: a systematic review and network meta-analysis. Diabetologia 55:566-578

3. Casas JP, Chua W, Loukogeorgakis S et al (2005) Effect of inhibitors of the renin-angiotensin system and other antihypertensive 
drugs on renal outcomes: systematic review and meta-analysis. Lancet 366:2026-2033

4. ADA (2012) Executive summary: standards of medical care in diabetes-2012. Diabetes Care 35(Suppl 1):S4-S10

5. Lewis EJ, Hunsicker LG, Clarke WR et al (2001) Renoprotective effect of the angiotensin-receptor antagonist irbesartan in patients with nephropathy due to type 2 diabetes. N Engl J Med 345:851860

6. Imai E, Chan JC, Ito S et al (2011) Effects of olmesartan on renal and cardiovascular outcomes in type 2 diabetes with overt nephropathy: a multicentre, randomised, placebo-controlled study. Diabetologia 54:2978-2986 